\title{
An assessment of water quality index of Godavari river water in Nashik city, Maharashtra
}

\author{
Ashali Chandrakant Kharake' ${ }^{1}$ Vaishali Sanjay Raut ${ }^{2}$
}

Received: 19 March 2020 / Accepted: 18 May 2021 / Published online: 2 June 2021

(c) The Author(s) 2021

\begin{abstract}
Water resource is most essential basic resource for human being. Today water resource management has become an important issue (Kharake, Pathare, Deshmukh, Arebian J Geosci 14(10):1-10, 2021) for all developing countries. Rapid growth of population and its repetitive activities along the river pose a concerned impact on the river system. The water quality and quantity are under constant pressure by the presence of different human activities like removal of vegetation, industrial activities, and encroachment, domestic and religious activities. These all activities resulted in degradation of water quality. These all problems are largely concentrated in and around urban areas. Keeping this view in the account systematic study has been carried out the water quality of Godavari river in Nashik city. Water samples from 10 sampling stations have been collected during 1st week of June 2019. Physico-chemical parameters have been analyzed by standard method. The Karl Pearson correlation matrix has been established for examining relationship between the water quality parameters, and the study is conducted to analyze the water quality status of Godavari river in terms of water quality index (WQI). The overall values showed good water quality status (WQI 133.44) at upper stream in the study area, but as it enters in urban area water quality becomes deteriorate (WQI 35.01). The field observations reveal that water quality is declining due to many human activities mainly industrial, domestic and religious waste. To analyze the water quality index (WQI) is the main aim of the research with remedial measures to mitigate the deterioration and related consequences in future.
\end{abstract}

Keywords Water quality · Water quality index · Godavari river · Physico-chemical analysis · The Karl Pearson correlation matrix

\section{Introduction}

Hydrosphere is an important segment of environment including $0.3 \%$ of the fresh water on Earth, and it is easily accessible from lakes, reservoirs and river systems (UNESCO 1998). Water plays an important role in various life processes of living organisms, in which river water is a precious natural resource for human being. Many human activities like agriculture, industrial, tourism and domestic, etc., depend upon the river. River has great potential of economic change (Patil et al. 2013). Many villages which are situated along river experienced rapid economic changes;

Ashali Chandrakant Kharake

ashali.kharake.27@gmail.com

1 Department of Geography, K.V.N.Naik College, Nashik, Maharashtra, India

2 Department of Chemistry, K.V.N.Naik College, Nashik, Maharashtra, India many of them were converted into important towns and cities (Kharke 2008). It has been observed that from past few decades population growth, urbanization (Muhammad et al. 2018), industrialization (Isai et al. 2015) and encroachments have put immense pressure on the river system (Bora and Goswami 2017). Many human activities related to economic development (Unde and Turkunde 2008) are responsible for water quality deterioration (Zhaoshi et al. 2017). It leads to degradation of water quality (Das 2013). Rivers have capacity to detoxify a certain quantity of pollutants discharged into them (Koichi and Hong-Ying 2010), but if the discharge of pollutants exceeds (Wu et al. 2017), water quality deteriorates (Govorushko 2010). Unpleasant taste of drinking water (Marle 2011), disgusting odor from lakes, river and beaches unmonitored growth of aquatic weeds and decrease in number of fishes are some of indications of water pollution; to understand chemical phenomenon occurring in water body, certain general criteria of water quality are applied such as $\mathrm{pH}, \mathrm{DO}, \mathrm{BOD}$, TDS. $\mathrm{pH}$ is indicator of concentration 
$\mathrm{H}+$ ions (Nag et al. 2018) in water natural water containing $\mathrm{HCO}_{3}{ }^{-}, \mathrm{CO}_{3}{ }^{-2}$ and $\mathrm{OH}^{-}$. These are main contributors of $\mathrm{pH}$ of water. $\mathrm{pH}$ of natural water is in the range of 3-10. Total dissolved solids (TDS) comprise inorganic salts (principally calcium, magnesium, potassium, sodium, bicarbonates, chlorides and sulfates), and some small amounts of organic matter are dissolved in water. TDS in water originates from natural sources, sewage, urban run-off, industrial waste water and chemicals used in the water treatment process (Patel et al. 2019a, b; Tyagi et al. 2013). Change in TDS is an indicator of water pollution (Duan et al. 2018). One more important parameter is dissolved oxygen (DO), which is a measure of how much oxygen is dissolved in the water. DO can tell us a lot about water quality (Popovic et al. 2016). Bacteria in the water consume oxygen when organic matter decays. Thus, excess organic material in rivers can cause eutrophic conditions, in which there is a deficiency of oxygen, which can cause a water body to "die." Measurement of many other parameters like BOD, Fecal coli also can help us to understand pollution of water body. Together they are summarized in the form of WQI (Sehnaz et al. 2017).

Nashik is an important industrial town in Maharashtra that has 125 large-, 350 medium- and 2500 small-scale units (Chavan et al. 2009) presently working in the upper part of the city. Godavari river is a major source of water for drinking, agriculture, domestic and industrial purposes. Nashik is also well known for religious tourism because the city is home of hundreds of temples. To understand inappropriate human activities and its impact on water quality is the main objective of the paper.

Water quality index is used to understand a general water quality status of water resource (Nadikatla et al. 2020); hence, it has been used to determine the water quality of surface and ground water quality (Akumtoshi et al. 2020; Phadatare et al. 2016). Number of studies are carried out related to water quality index (WQI) (Khound and Bhattacharya 2018; Horton 1965) used WQI for first time as an indicator of water pollution. Brown et al. (1970) also calculated WQI by basic arithmetic weighting, but without multiplicative variables these efforts were supported by National Sanitation Foundation (NSF) in which water quality variables were calculated using the Delphi method (Dalkey 1968). Bhargava (1983) also suggested water quality index for river Ganga. Ichwana and Nelly (2016), Shah and Joshi (2017), Bora and Goswami (2017), Verma et al. (2019) and Akukumtoshi et al. (2020) have calculated WQI for different rivers.

The main objective of the present study is to develop simplified WQI in order to examine the effects of anthropogenic activities on water quality of Godavari river in Nashik city. Further research will helpful to minimize activities which are responsible for water contamination and for creating awareness among local people, farmers and entrepreneur, etc.

\section{Study area}

For the present study Nashik city has been selected. It located in the north-west direction of Maharashtra, at a height of $700 \mathrm{~m}$. It is situated at $19^{\circ} 33^{\prime}$ to $20^{\circ} 53^{\prime}$ north latitude and $73^{\circ} 16^{\prime}$ to $75^{\circ} 6^{\prime}$ east longitude and on the bank of the Godavari river. The average annual temperature of Nashik city is $24^{\circ} \mathrm{C}$, and about $812 \mathrm{~mm}$ of precipitation falls annually. According to the 2011 census Nashik city has 1,486,973 populations. For the investigation of Godavari river water quality the channel from the Gangapur dam to Dasak village is selected which has a length of $24 \mathrm{~km}$. From above channel 10 sampling stations have been selected for water quality analysis (Fig. 1)..

\section{Materials and methods}

For further study 10 sampling stations within Nashik city have been selected. Selection of sampling stations is based on types of human activities and their intensity as well as area affected by urban waste. For water quality analysis water samples have been collected from the surface water along the river. Temperature and $\mathrm{pH}$ of samples have been measured in the field during collection. The water samples were analyzed at Water Quality Laboratory level-II, Nashik under Hydrology Project, water resources department, Government of Maharashtra. The analysis was carried out in the laboratory as per BIS standard methods. Various physico-chemical parameters like total dissolved solids (TDS), dissolved oxygen (DO), biological oxygen demand (B.O.D.) (Yogendra and Puttaiah 2008), total solids and turbidity were analyzed to evaluate the impact of urban waste on water quality. The Karl Pearson correlation matrix has been established to examine the relationship between the water quality parameters. The data were analyzed for water quality status, and water quality index was determined by the formula developed by NSF (National Sanitation Foundation) and modified by CPCB (Central Pollution Control Board) (Table 1) which depicts the water quality in simple and easy way. WQI as it gives a single number that expresses the overall water quality of a certain water sample (location and time specific) for several water quality parameters. It all information summarized and analyzed with the help of graphs (Tables 2, 3).

$\mathrm{WQI}=\sum_{i=1}^{P} \mathrm{Wili}$ 


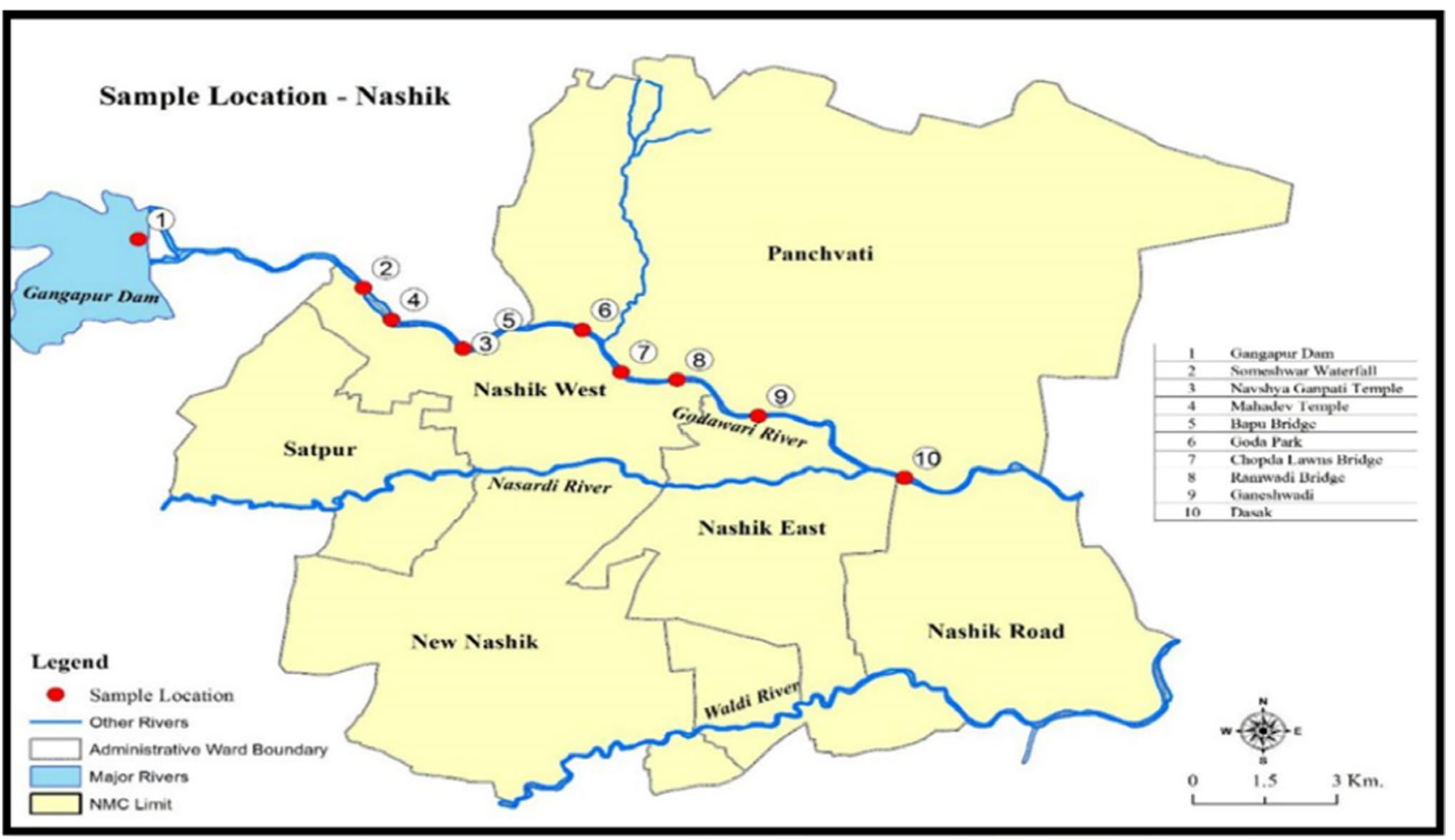

Fig. 1 Location map of study area

Table 1 Modified weights for computation of WQI based on DO, FC, $\mathrm{pH}$ and BOD

\begin{tabular}{lll}
\hline Sr. no & Parameters & Weight \\
\hline 1 & Dissolved oxygen & 0.31 \\
2 & pH & 0.28 \\
3 & BOD & 0.22 \\
4 & Fecal coli & 0.19 \\
& $\mathbf{\Sigma}$ Wi & $\mathbf{1 . 0 0}$ \\
\hline
\end{tabular}

\section{Results and discussion}

The analysis report of sample sites has been carried out as per BIS limits, which are given in Table 4 .

We investigated the river behavior by measuring 8 parameters (Table 4) showing values of measured values of various parameters. Data show that water pollution increases as the river flows through the urban area in which $\mathrm{pH}$ values show alkaline or acidic behavior of water, TS and TDS affecting
Table 2 Subindex equation used to calculate NSF WQI for DO, $\mathrm{FC}, \mathrm{pH}$ and BOD

\begin{tabular}{|c|c|c|}
\hline Water quality parameters (Units) & Range applicable & Equation \\
\hline \multirow[t]{3}{*}{ Dissolved oxygen (DO) (\% saturation) } & $0-40$ & $0.18+0.66 \times \%$ saturation DO \\
\hline & $40-100$ & $(-13.55)+1.17 X \%$ saturation DO \\
\hline & $100-140$ & $163.34-0.62 \mathrm{X} \%$ saturation DO \\
\hline \multirow[t]{3}{*}{ Fecal Coliform (FC) (counts/100 ml) } & $1-10^{3}$ & $97.2-26.6^{*} \log \mathrm{FC}$ \\
\hline & $10^{3}-10^{5}$ & $42.33-7.75 * \log \mathrm{FC}$ \\
\hline & $>10^{5}$ & 2 \\
\hline \multirow[t]{5}{*}{$\mathrm{pH}$} & $02-05$ & $16.1+7.35 *(\mathrm{pH})$ \\
\hline & $05-7.3$ & $(-142.67)+33.5^{*}(\mathrm{pH})$ \\
\hline & $7.3-10$ & $316.96-29.85 * \mathrm{pH}$ \\
\hline & $10-12$ & $96.17-8 * \mathrm{pH}$ \\
\hline & $<2,>12$ & 0 \\
\hline \multirow[t]{3}{*}{ BOD (mg/l) } & $0-10$ & $96.67-7 * \mathrm{BOD}$ \\
\hline & $10-30$ & $38.9-1.23 * \mathrm{BOD}$ \\
\hline & $>30$ & 2 \\
\hline
\end{tabular}


Table 3 Water quality classification and best designated use

\begin{tabular}{|c|c|c|c|c|}
\hline Sr. No. & WQI & $\begin{array}{c}\text { Class by } \\
\text { CPCB }\end{array}$ & Remarks & Color Code \\
\hline $\mathbf{1}$ & $63-100$ & A & Non Polluted & \\
\hline $\mathbf{2}$ & $50-63$ & B & Non Polluted & \\
\hline $\mathbf{3}$ & $38-50$ & C & Polluted & \\
\hline $\mathbf{4}$ & 38 and less & D,E & $\begin{array}{l}\text { Heavily } \\
\text { Polluted }\end{array}$ & \\
\hline
\end{tabular}

Table 4 The parameters of the Godavari river at Nashik city (June 2019)

\begin{tabular}{|c|c|c|c|c|c|c|c|c|c|}
\hline Station No & Location & $\begin{array}{l}\text { Temperature } \\
\left(\text { in }{ }^{\circ} \mathrm{C} \text { ) }\right.\end{array}$ & PH & $\mathrm{TS}$ & DO & TDS & Turbidity & BOD & F-coli (MPN) \\
\hline S1 & Gangapur dam & 23.4 & 8.7 & 66 & 7.5 & 60 & 4.6 & 2.5 & 2 \\
\hline $\mathrm{S} 2$ & Someshwar water fall & 23.9 & 8.2 & 80 & 7.3 & 70 & 5.0 & 3.0 & 2.5 \\
\hline $\mathrm{S} 3$ & Navsya Ganpati & 24.2 & 8.5 & 156 & 7.2 & 82 & 5.3 & 3.5 & 5.8 \\
\hline S4 & Rameshwar Mahadev Temple & 23.8 & 8.3 & 170 & 4.1 & 94 & 8.4 & 20 & 7.8 \\
\hline S5 & Bapu Bridge & 24 & 7.8 & 250 & 3.2 & 156 & 9.1 & 35 & 19 \\
\hline S6 & Goda park & 24.9 & 8.0 & 389 & 3.1 & 182 & 10.7 & 40 & 12 \\
\hline S7 & Chopra Lawns Bridge & 25.3 & 8.5 & 416 & 1.9 & 314 & 15.42 & 52 & 25 \\
\hline S8 & Ramwadi Bridge & 24.7 & 8.3 & 381 & 2.0 & 216 & 15.48 & 50 & 22 \\
\hline S9 & Ganesh wadi & 24.8 & 7.8 & 372 & 2.0 & 369 & 15.59 & 38 & 24 \\
\hline S10 & Dasak Bridge & 26 & 7.5 & 616 & 3.4 & 412 & 24.97 & 42 & 28 \\
\hline
\end{tabular}

Required desirable limits—as per standards prescribed For Drinking Water by Bureau of Indian Standards, 2002 (BIS) limits, 2012

turbidity of water. The increased number of coliform germs indicates pollution, which comes from waste waters from households in the surrounding settlements. The increased values of BOD indicate the biological activity of the waste waters and are the main organic pollution indicator.

\section{pH}

$\mathrm{pH}$ is an indicator of the amount of hydrogen ion concentration value. It is used to indicate acidity or basicity of the water. Normal water a has $\mathrm{pH}$ value between 6.5 and 7.5. Sewage into water can change the hydrogen ion concentration $(\mathrm{pH})$ in the water, and it became more alkaline depending on the types of waste and chemical substances contained in them (Ichwana et al. 2016). Change of $\mathrm{pH}$ can change the heart rate, curve spin and shape of the head (Shinde et al. 2019). The present study shows that water at various stations is alkaline. The $\mathrm{pH}$ value has been ranging between 7.5 and 8.7 at various sampling sites.

\section{TS}

Total solids are dissolved solids in the water, including suspended and settleable solids. Total solids ranged between 66 and $616 \mathrm{mg} / \mathrm{l}$ at various sampling sites. TS has been suddenly increased from $S_{7}$ to $S_{10}$ (distance $11.5 \mathrm{~km}$ ), and it may due to the direct input of massive local discharge from city. It is all responsible to make water unpalatable.

\section{DO}

Dissolved oxygen in the water is an important index in determining the purity of water. It gives nature of organic matter present in water. DO is essential for healthy aquatic life. The DO values ranged between 1.9 and 7.5. It is observed that DO of river water between $S_{4}$ and $S_{10}(13.5 \mathrm{~km})$ is less than $5 \mathrm{mg} / \mathrm{l}$, and it may due to contamination of urban waste during journey of the river. Godavari river deteriorates (Bawa and Gaikwad 2013).

\section{TDS}

TDS also shows similar trends due to contamination of sewage in the river. It has suddenly increased from $S_{7}$ to $S_{10}$ due to the high density of population which is responsible for emanation of large amount of solid waste, discharge of domestic wastewater, encroachment and sewages. As most of the major pathogenic diseases, hazards and dermatological 
problems, are recognized due to consumption of polluted water (Koli et al. 2018), the river is supposed most suitable place to dump garbage waste and it is proved as a major load on the river, it increases TDS in water, and it causes unhygienic atmosphere and creating health problems like malaria, diarrhea, etc.

\section{Turbidity}

Turbidity is description of the optical properties of water which is calculated by amount of light emitted and absorbed by particles in the water (Ichwana et al. 2016).
It is observed that turbidity goes on increasing from $\mathrm{S}_{3}$ to $\mathrm{S}_{10}(14 \mathrm{~km})$ and it is maximum at $\mathrm{S}_{10}(24.97 \mathrm{NTU})$ again due to organic pollutant like cremate and discharge of ash of human dead bodies as well as to perform religious activities flower garlands and other solid waste directly added to the water.

\section{BOD}

BOD is the amount of oxygen consumed in biodegradation of organic matter during period of 5 days. It can be observed (Table 1) there is suddenly increase of BOD value from $\mathrm{S}_{4}$,
Fig. $2 \mathrm{pH}$ of selected sampling stations

Fig. 3 TS of selected sampling stations
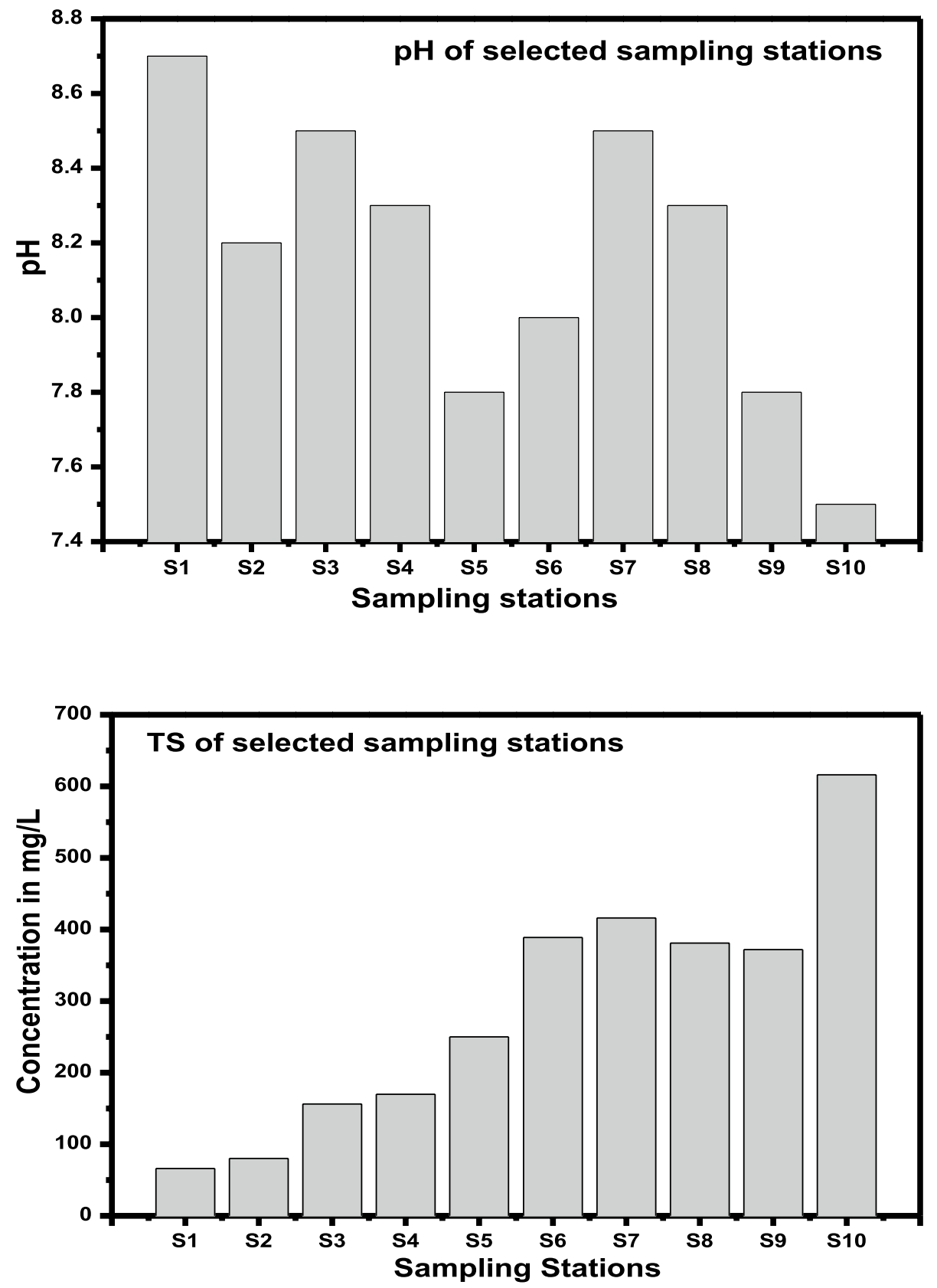

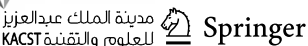


Fig. 4 DO of selected sampling stations

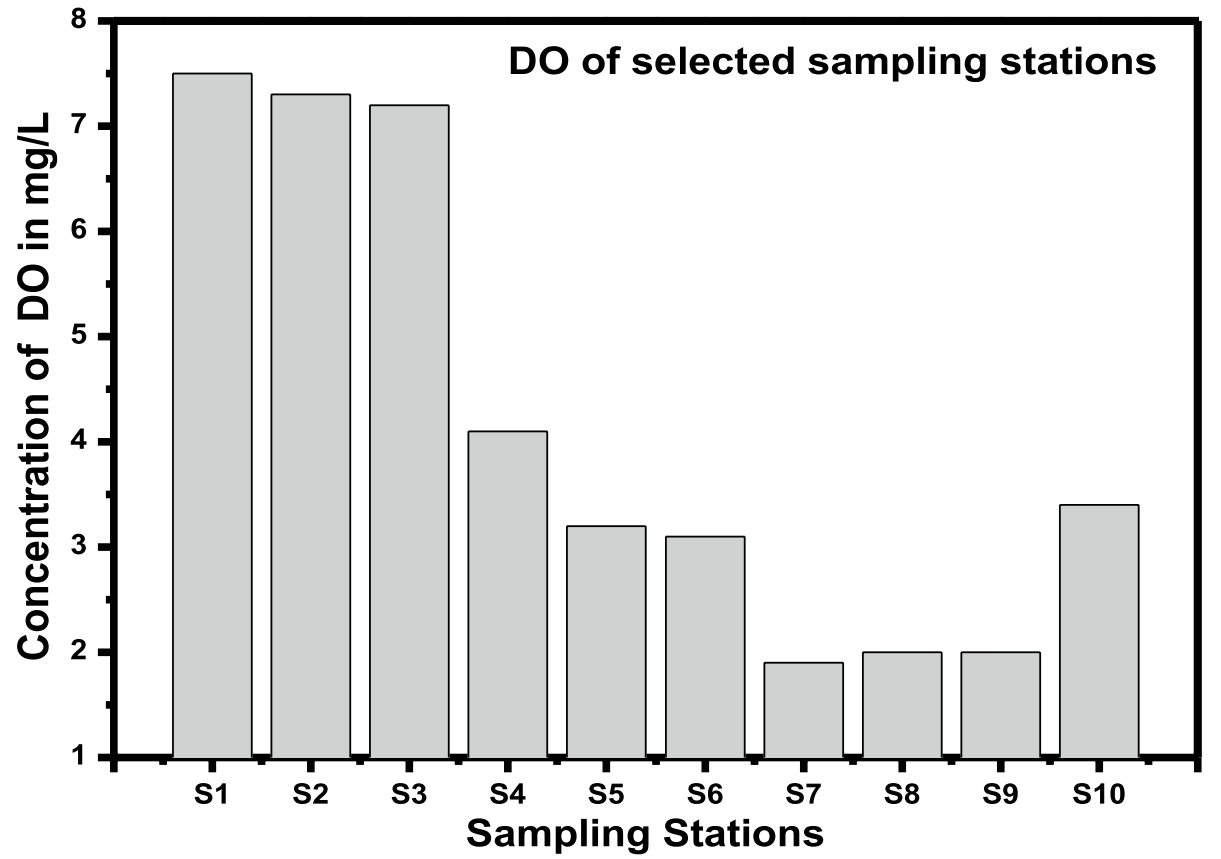

Fig. 5 TDS of selected sampling stations

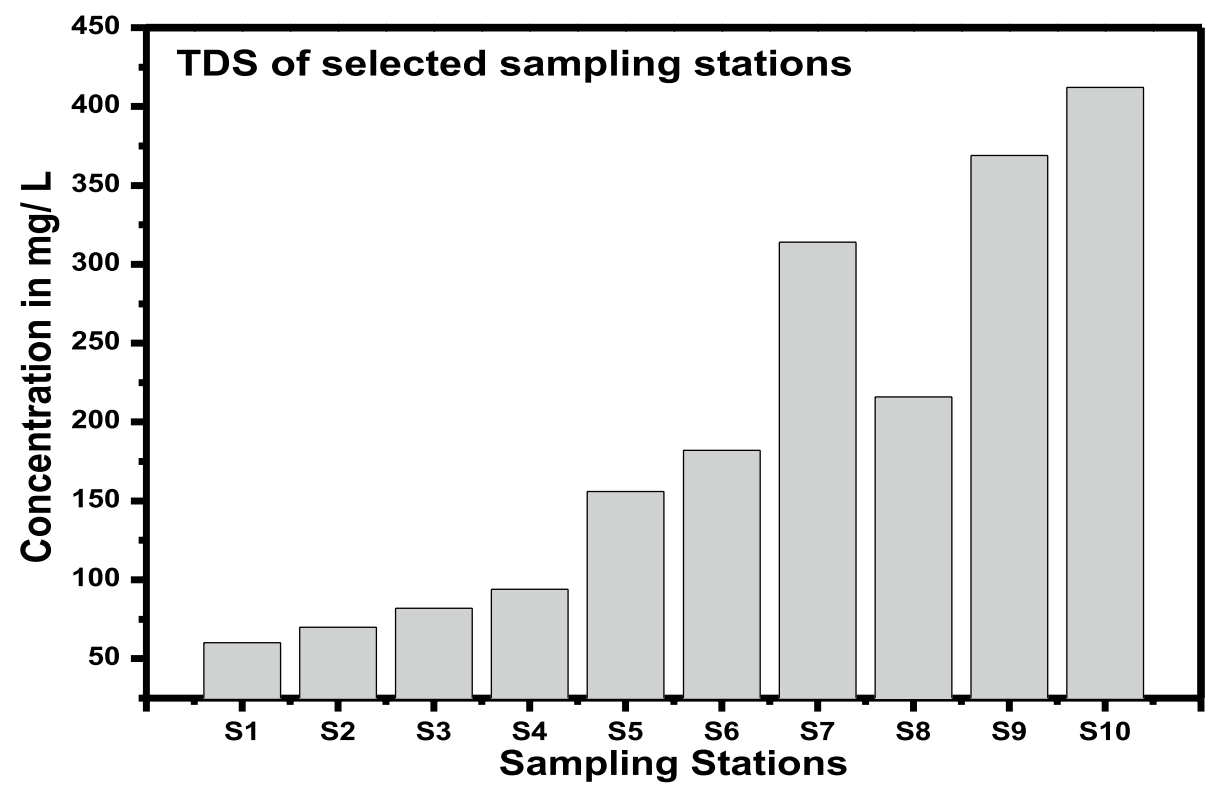

and it may be due to sewage entering in the Godavari river by nalas coming out of industrial areas, hotels and slums nearby the river bank. BOD at $S_{7}$ and $S 8$ is found to be highest although no point source is observed here, lots of waste water from weekly market and vehicle washing which are responsible for contamination (Table 5, 6; Figs. 2, 3, 4, 5, $6,7,8,9))$.
The Karl Pearson correlation matrix has been established for examination of the relationship between two parameters of the samples. The value of correlation coefficient around 0.7 and above (Bawa and Gaikwad 2013) is considered to be a strong positive correlation. It has been found from analysis that positive correlation is found between turbidity and total dissolved solids. Positive correlation also found between turbidity and TDS (Table 6). This is due to fact as the number of particles in water (TDS) increases, so turbidity also has been increased. It can be seen that there is a positive 
Fig. 6 Turbidity of selected sampling stations

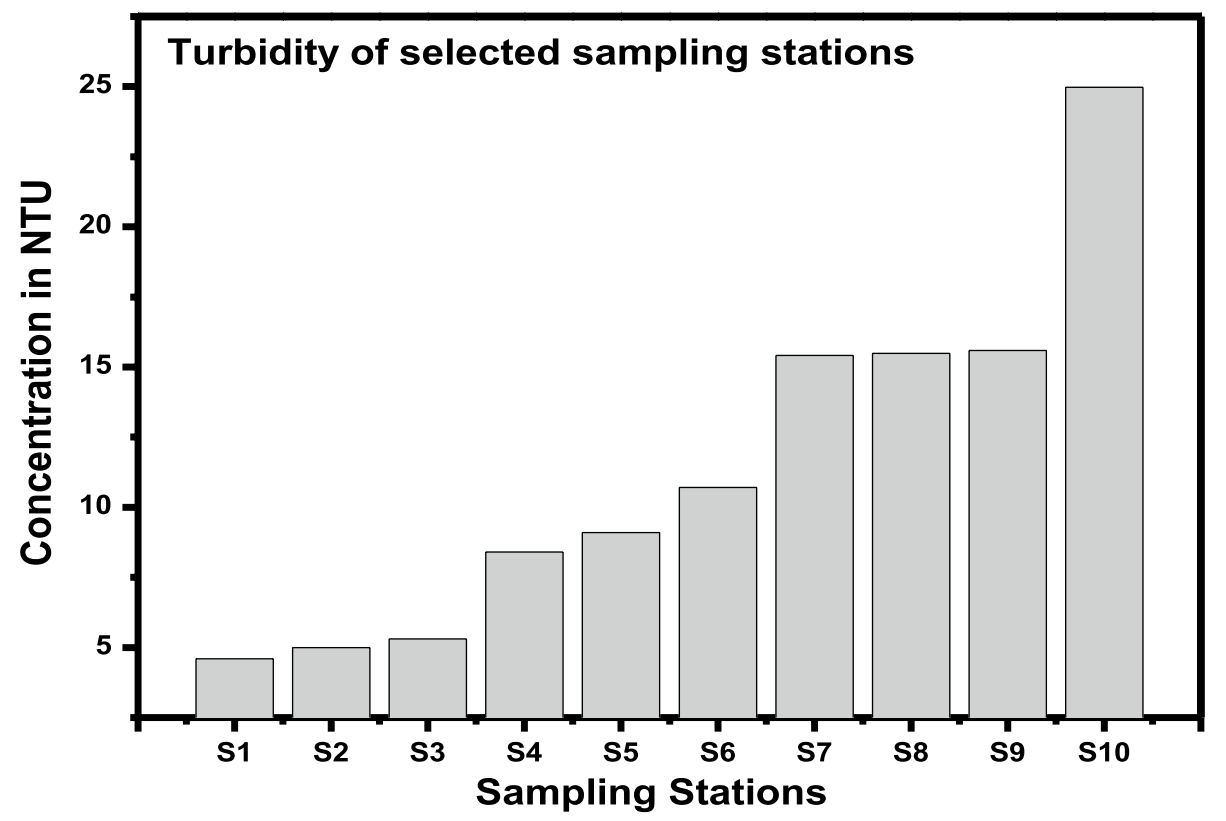

Fig. 7 BOD of selected sampling stations

correlation between BOD and TS, higher the BOD values which arise TS presents in the water. There is positive correlation between BOD and turbidity as amount of suspended matter increases turbidity which in turn increases BOD value (Table 7, 8).

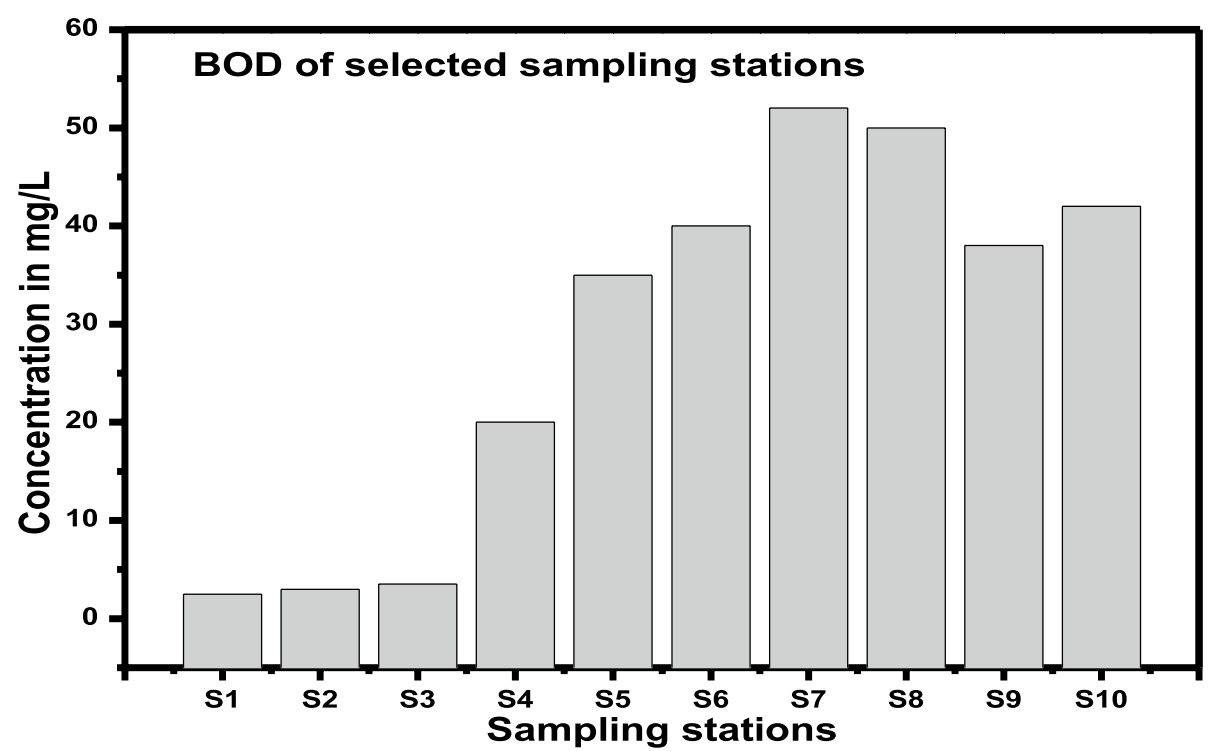

\section{Conclusions}

In this study water quality of Godavari river in Nashik city was evaluated, to evaluate water quality of Godavari river 10 sampling stations were determined, and 8 parameters were selected. The physico-chemical analysis of water samples indicates that the river water sample has alkaline properties. As pollutants are added in the river water at various stations, it has decreased dissolved oxygen value. Due to addition of pollutant at these stations BOD and 
Fig. 8 F-coli of selected sampling stations

Fig. 9 WQI of collected water samples
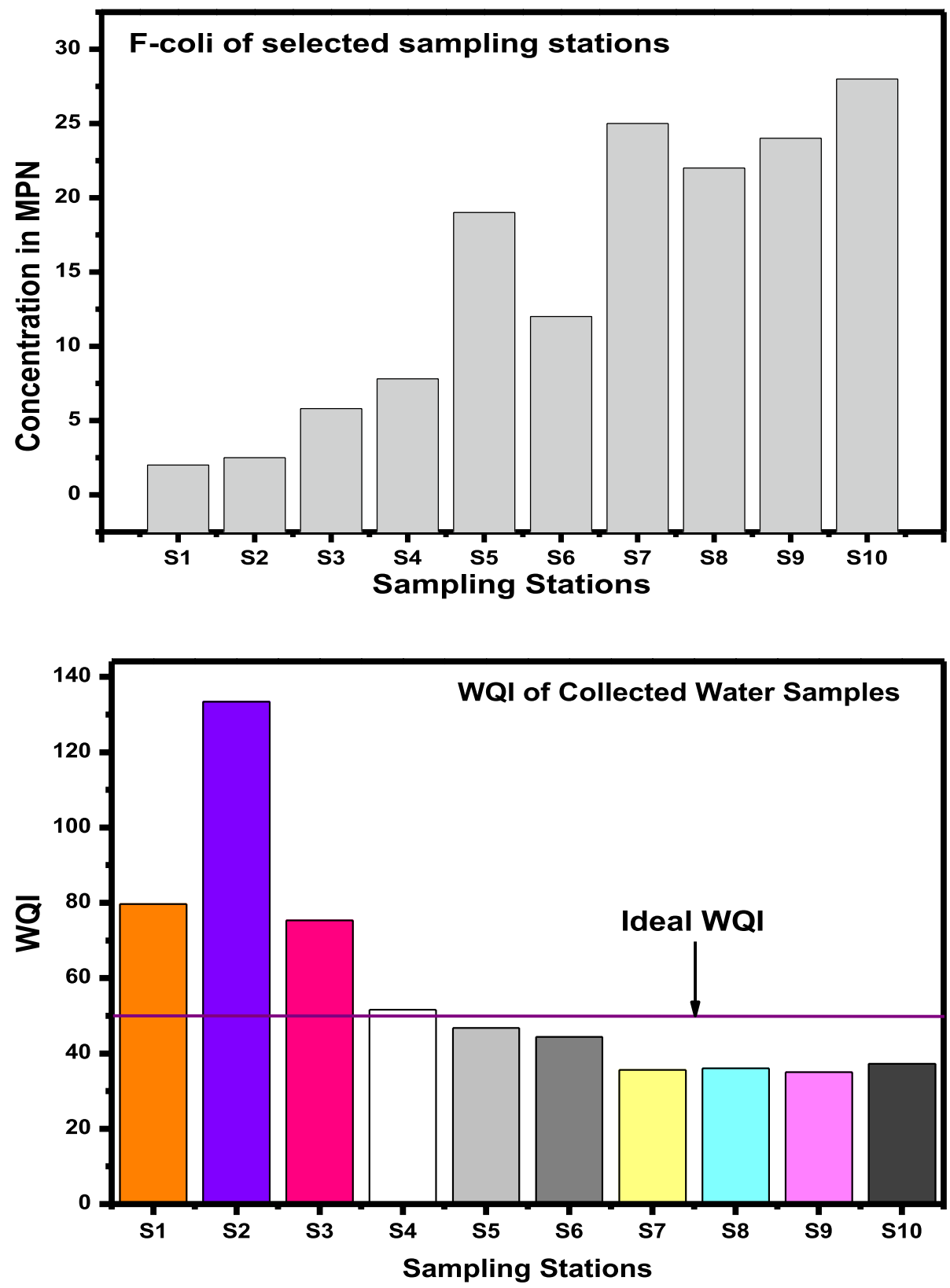

Table 5 Statistical summary of physico-chemical parameters

\begin{tabular}{lllll}
\hline Parameters & Max & Min & Mean & Sum \\
\hline pH & 8.7 & 7.5 & 8.1 & 81.6 \\
TS & 616 & 66 & 341 & 2896 \\
DO & 7.5 & 1.9 & 4.7 & 41.7 \\
TDS & 412 & 120 & 266 & 1955 \\
Turbidity & 24.97 & 4.6 & 14.7 & 114.56 \\
BOD & 52 & 2.5 & 27.25 & 286 \\
\hline
\end{tabular}

Max—maximum, Min—minimum turbidity values have increased. TDS and F-coli parameters showed increased value at $\mathrm{S}_{10}$ due to sewage and burial activities.

Water quality parameters $\mathrm{pH}, \mathrm{DO}, \mathrm{BOD}$ and F-coli were used to calculate water quality index (WQI) for evaluation of water quality. The water quality index values of Godavari river of about $24 \mathrm{~km}$ the stench from Gangapur dam to Dasak Bridge show that due to urban slums, weekly markets and religious tourism lots of urban waste have been generated. It may be in liquid or solid forms responsible 
Table 6 Karl Pearson correlation matrix for water samples of Godavari river water in Nashik city (June 2019)

\begin{tabular}{lcccccc}
\hline Parameters & $\mathrm{pH}$ & $\mathrm{TS}$ & $\mathrm{DO}$ & $\mathrm{TDS}$ & Turbidity & BOD \\
\hline $\mathrm{pH}$ & 1.0 & & & & & \\
TS & -0.6430 & 1.0 & & & & \\
DO & 0.4718 & -0.7704 & 1.0 & & & \\
TDS & -0.6297 & $\mathbf{0 . 9 1 3 7}$ & -0.7437 & 1.0 & & \\
Turbidity & -0.6395 & $\mathbf{0 . 9 5 7 8}$ & -0.7181 & $\mathbf{0 . 9 3 9 7}$ & 1.0 & \\
BOD & -0.4523 & $\mathbf{0 . 8 5 6 5}$ & -0.9632 & 0.7776 & 0.7888 & 1.0 \\
\hline
\end{tabular}

Computed by Researchers

Table 7 Godavari river water sampling stations and observed urban waste

\begin{tabular}{lllll}
\hline Station no & Location & $\begin{array}{l}\text { Distance from 1st } \\
\text { sampling station }(\mathrm{km})\end{array}$ & Coordinates & Observed urban waste \\
\hline S1 & Gangapur dam & 00 & $20^{\circ} 0 ; \mathrm{N} 73^{\circ} 66^{\prime \prime} \mathrm{E}$ & Tourism \\
S2 & Someshwar water fall & 7.7 & $20^{\circ} 0 ; \mathrm{N} 73^{\circ} 66^{\prime \prime} \mathrm{E}$ & Tourism, Bathing etc \\
S3 & Navsya Ganpati & 10 & $20^{\circ} 0^{\prime} \mathrm{N} 73^{\circ} 67 \mathrm{E}$ & Religious tourism \\
S4 & Someshwar Mahadev Temple & 10.5 & $20^{\circ} 0^{\prime} \mathrm{N}$ to $73^{\circ} 68^{\prime} \mathrm{E}$ & Religious tourism \\
S5 & Bapu Bridge & 11 & $20^{\circ} 0^{\prime} \mathrm{N}$ to $73^{\circ} 68^{\prime} \mathrm{E}$ & Sewage from Anandwalli slums \\
S6 & Goda park & 11.5 & $20^{\circ} 0^{\prime} \mathrm{N}$ to $73^{\circ} 69^{\prime} \mathrm{E}$ & Untreated sewage from hotels and local tourists \\
S7 & Chopra Lawns Bridge & 12.5 & $20^{\circ} 0^{\prime} \mathrm{N}$ to $73^{\circ} 70^{\prime} \mathrm{E}$ & Sewage from industries \\
S8 & Ramwadi Bridge & 15 & $20^{\circ} 0^{\prime} \mathrm{N}$ to $73^{\circ} 78^{\prime} \mathrm{E}$ & Religious tourism \\
S9 & Ganesh wadi & 16 & $20^{\circ} 0^{\prime} \mathrm{N}$ to $73^{\circ} 78^{\prime} \mathrm{E}$ & Waste from rituals and weekly market \\
S10 & Dasak Bridge & 24 & $20^{\circ} 0^{\prime} \mathrm{N}$ to $73^{\circ} 78^{\prime} \mathrm{E}$ & Sewage from different industries, domestic activities \\
\hline
\end{tabular}

Personal investigation

Table 8 WQI rating of various sampling sites of Godavari river

\begin{tabular}{|c|c|c|c|}
\hline Sr. No. & Stations & WQI & Color Code \\
\hline $\mathbf{1}$ & Gangapur Dam & 79.67 & \\
\hline $\mathbf{2}$ & Someshwar Waterfall & 133.44 & \\
\hline $\mathbf{3}$ & Navsya Ganpati & 75.30 & \\
\hline $\mathbf{4}$ & Rameshwar Mahadev Temple & 51.59 & \\
\hline $\mathbf{5}$ & Bapu Bridge & 46.8 & \\
\hline $\mathbf{6}$ & Goda Park & 44.34 & \\
\hline $\mathbf{7}$ & Chopra Bridge & 35.6 & \\
\hline $\mathbf{8}$ & Ramwadi Bridge & 36.01 & \\
\hline $\mathbf{9}$ & Ganesh wadi & 35.01 & \\
\hline $\mathbf{1 0}$ & Dasak Bridge & 37.24 & \\
\hline
\end{tabular}

for water pollution. The computed WQI values are between 35.01 and 133.44 in the study area. The WQI classification shows that $S_{2}$ has good water quality status, but as it enters in city considerable changes in WQI were observed at $\mathrm{S}_{7}, \mathrm{~S}_{8}$ and $\mathrm{S}_{9}$ sites due to burial activities, encroachment and contamination. In spite of all efforts made by 
government authorities, local people and entrepreneur are not aware about river pollution. From the above analysis, it has been concluded that the acceleration of population increases the human interventions along the river which deteriorate the water quality. Hence, the suggested measures would help to minimize human interventions in and along the river Godavari. It is also helpful to minimize negative consequences of such impacts in the future and conserve the water resource.

Funding There is no funding utilized for current research work.

\section{Declarations}

Conflict of interest The authors declare that they have no conflict of interest.

Human Participants and/or Animals This article does not contain studies with human or animal subjects.

Informed consent We fully agree with the information provided in this article.

Authors Contribution Ashali Kharake helped in writing-original draft preparation, conceptualization, methodology, map-preparation. Vaishali Raut involved in writing — original draft preparation and data curation.

Open Access This article is licensed under a Creative Commons Attribution 4.0 International License, which permits use, sharing, adaptation, distribution and reproduction in any medium or format, as long as you give appropriate credit to the original author(s) and the source, provide a link to the Creative Commons licence, and indicate if changes were made. The images or other third party material in this article are included in the article's Creative Commons licence, unless indicated otherwise in a credit line to the material. If material is not included in the article's Creative Commons licence and your intended use is not permitted by statutory regulation or exceeds the permitted use, you will need to obtain permission directly from the copyright holder. To view a copy of this licence, visit http://creativecommons.org/licenses/by/4.0/.

\section{References}

Akumtoshi L, Singh MR, Puro N (2020) Assessment of water quality status of Doyang River, Nagaland, India, using Water Quality Index. Appl Water Sci 10(1):1-13

Bawa KV, Gaikawad VB (2013) Water quality assessment of Godavari River at Nashik, India: impact of sewage and industrial wastewater. Univ J Environ Res Technol 3(4): 452-457. ISSN 22490256.

Bhargava DS (1983) Use of a water quality index for river classification and zoning of the Ganga River. Environ Pollut Ser B 6:51-67

Bora M, Goswami DC (2017) Water quality assessment in terms of water quality index (WQI): case study of the Kolong River, Assam. India Appl Water Sci 7(6):3125-3135

Brown RM, McClelland NI, Deininger RA, Tozer RG (1970) A water quality Index- do we dare. Water Sew Works 117:339-343

Chavan AD, Sharma MP, Bhargava R (2009) Water quality assessment of the Godavari River. Hydro Nepal J Water Energy Environ $5: 31-34$
Dalkey NC (1968) DELPHI. The Rand Corporation, Santa Monica

Das DN (2013) The impact of industrial and urban activities on the water quality of Tunia River, Assam. Unpublished Ph.D. Thesis submitted to Gauhati University, Assam.

Duan W, Meng F, Cui H, Lin Y, Wang G, Wu J (2018) Ecotoxicity of phenol and cresols to aquatic organisms: a review. Ecotoxicol Environ Safety 157:441-456

Govorushko SM (2010) Effect of Human activity on Rivers International Congress on River Basin Managemant, pp 464-476

Horton RK (1965) An index number system for rating water quality. Water Pollute Control Fed 37:300-306

Ichwana S, Nelly W (2016) Water quality Index by using National Sanitation Foundation-Water quality Index (NSF-WQI). International conference on technology innovation and society.

Isai KA, Shrivastava VS (2015) Detection and identification of organics and metals from industrial wastewater by ICP-AES, FTIR and GC-MS. J Adv Chem Sci 1(04):164-166

Kharke AC (2008) Analysis of Geo-environmental effects due to human interventions along Pravara River at Sangamner city, Ahmednagar, Maharashtra. Multidiscip Approaches Remote Sens GIS 1(1): 89-93, ISSN: 2319-8648

Kharake A, Pathare J, Deshmukh P (2021) Spatio-temporal variability of intra-monsoonal rainfall in Pravara-Mula river basin, India. Arebian J Geosci 14(10):1-10

Khound NJ, Bhattacharyya KG (2018) Assessment of water quality in and around Jia-Bharali river basin, North Brahmaputra Plain, India, using multivariate statistical technique. Appl Water Sci 8(8): 221

Koichi F, Hong-Ying HU (2010) Effects of human activities on water quality. In: Water quality and standard

Koli PB, Kailas HK, Uday GD (2018) Study of physico-chemical properties, detection and toxicity study of organic compounds from effluent of MIDC Thane and GIDC Ankleshwar industrial zone. Appl Water Sci 8:196. https://doi.org/10.1007/s13201-018-0843-2

Kumar A, Dua A (2009) Water quality index for assessment of water quality of river Ravi at Madhopur (India). Glob J Environ Sci 8:1

Marle SM (2011) Assessment of pilgrimage impact on river water quality and health along river Indrayani, District Pune. Unpublished Ph.D. Thesis submitted to Savitribai Phule Pune University.

Muhammad AHR, Malik MM, Sana M (2018) Urbanisation and its effects on water recourses: an exploratory Analysis. Asian J Water Environ Pollut 15(1):67-74

Nadikatla SK, Mushini VS, Mudumba PSMK (2020) Water quality index method in assessing groundwater quality of Palakonda mandal in Srikakulam district, Andhra Pradesh, India. Appl Water Sci 10(1):30

Nag SK, Kundu A (2018) Application of remote sensing, GIS and MCA techniques for delineating groundwater prospect zones in Kashipur block, Purulia district, West Bengal. Appl Water Sci 8(1):38

Obiora DN, Ibuot JC (2020) Geophysical assessment of aquifer vulnerability and management: a case study of University of Nigeria, Nsukka, Enugu State. Appl Water Sci 10(1):29

Patel SV, Chavda P, Tyagi S (2019) 'carrying out assessment of groundwater quality of villages of Bhavnagar district of Gujarat, India. Environ Claims J 31(1):79-92

Patel SV, Chavda P, Tyagi S (2019) Carrying out assessment of groundwater quality of villages of Bhavnagar District of Gujarat, India. Environ Claims J 311:79-92

Patil S, Ghorade IB (2013) Assessment of physico-chemical characteristics of Godavari river water at Trimbakeshwar and Kopargaon, Maharashtra. Indian J Appl Res 3(3):149-152

Phadatare SS, Gawande S (2016) Review paper on development of water quality index. Int J Eng Res Technol (IJERT) 5(5):765-767

Popovic NZ, Duknic JA, Atlagic JZ, Rakovic MJ, Marinkovic NS, Tubic BP, Paunovic MM (2016) Application of the water pollution 
index in the assessment of the ecological status of rivers: a case study of the Sava River, Serbia. Acta Zoologica Bulgarica 68(1):97-102

Şehnaz Ş, Erhan Ş, Ayşen D (2017) Evaluation of water quality

Shah KA, Joshi GS (2017) Evaluation of water quality index for River Sabarmati, Gujarat, India. Appl Water Sci 7(3):1349-1358

Shinde S, Shrivastava VS (2018) Physico-chemical assessment and analysis of hazardous organic substance from textile industrial effluents from Sachin and Kadodara, GIDC, Surat, India. Rev Res $8(02): 1-18$

Tyagi S, Sharma B, Singh P, Dobhal R (2013) Water quality assessment in terms of water quality index. Water Res 1(3):34-43

Unde M, Turkunde K (2008) Geo-environmental effects of urbanization in the river channel: a case study of River Sina around Ahmednagar city. Multidisciplinary Int Res J 1(03)

UNESCO (1998) World Water Resources: a New Appraisal and Assessment for 21 st century (Report) using water quality index (WQI) method and GIS in Aksu River (SW-Turkey). Sci Total Environ 584:131-144

Vaishali AC, Ashali K (2019) Water quality assessment of Pravara river at Sangamner Tehsil, Ahmednagar District, India: an impact of anthropogenic activities. Rev Res 08(05): 1-5, ISSN- 2249-894X
Verma RK, Murthy S, Tiwary RK, Verma S (2019) Development of simplified WQIs for assessment of spatial and temporal variations of surface water quality in upper Damodar river basin, Eastern India. Appl Water Sci 9(1):21

Wu Z, Zhang D, Cai Y, Wang X, Zhang L, Chen Y (2017) Water quality assessment based on the water quality index method in Lake Poyang: the largest freshwater lake in China. Sci Rep 7(1):1-10

Yogendra K, Puttaiah ET (2008) Determination of water quality index and suitability of an urban waterbody in Shimoga Town, Karnataka. In: Proceedings of Taal2007: The 12th world lake conference, vol 342, p 346

Zhaoshi W, Zhang D, Cai Y, Xiaolong W, Lu Z, Yuwei C (2017) Water quality assessment based on the water quality index method in Lake Poyang: the largest freshwater lake in China. Sci Rep 7:17999

Publisher's note Springer Nature remains neutral with regard to jurisdictional claims in published maps and institutional affiliations. 